\title{
Strategies for Biocontrol of Listeria monocytogenes Using Lactic Acid Bacteria and Their Metabolites in Ready-to-Eat Meat- and Dairy-Ripened Products
}

\author{
Irene Martín (D, Alicia Rodríguez, Josué Delgado and Juan J. Córdoba *D \\ Higiene y Seguridad Alimentaria, Facultad de Veterinaria, Instituto Universitario de Investigación de la Carne y \\ Productos Cárnicos, Universidad de Extremadura, Avda de las Ciencias, s/n, 10003 Cáceres, Spain; \\ iremartint@unex.es (I.M.); aliciarj@unex.es (A.R.); jdperon@unex.es (J.D.) \\ * Correspondence: jcordoba@unex.es
}

check for

updates

Citation: Martín, I.; Rodríguez, A.; Delgado, J.; Córdoba, J.J. Strategies for Biocontrol of Listeria monocytogenes Using Lactic Acid Bacteria and Their Metabolites in Ready-to-Eat Meat- and Dairy-Ripened Products. Foods 2022, 11, 542. https://doi.org/10.3390/ foods11040542

Academic Editor: Mónica

Flores Llovera

Received: 20 January 2022

Accepted: 7 February 2022

Published: 14 February 2022

Publisher's Note: MDPI stays neutral with regard to jurisdictional claims in published maps and institutional affiliations.

Copyright: (c) 2022 by the authors. Licensee MDPI, Basel, Switzerland. This article is an open access article distributed under the terms and conditions of the Creative Commons Attribution (CC BY) license (https:/ / creativecommons.org/licenses/by/ $4.0 /)$.

\begin{abstract}
Listeria monocytogenes is one of the most important foodborne pathogens. This microorganism is a serious concern in the ready-to-eat (RTE) meat and dairy-ripened products industries. The use of lactic acid bacteria (LAB)-producing anti-L. monocytogenes peptides (bacteriocins) and/or lactic acid and/or other antimicrobial system could be a promising tool to control this pathogen in RTE meat and dairy products. This review provides an up to date about the strategies of use of LAB and their metabolites in RTE meat products and dairy foods by selecting the most appropriate strains, by analysing the mechanism by which they inhibit L. monocytogenes and methods of effective application of $\mathrm{LAB}$, and their metabolites in these kinds of products to control this pathogen throughout the processing and storage. The selection of LAB with anti-L. monocytogenes activity allows to dispose of effective strains in meat and dairy-ripened products, achieving reductions form 2-5 logarithmic cycles of this pathogen throughout the ripening process. The combination of selected LAB strains with antimicrobial compounds, such as acid/sodium lactate and other strategies, as the active packaging could be the next future innovation for eliminating risk of L. monocytogenes in meat and dairy-ripened products.
\end{abstract}

Keywords: L. monocytogenes; LAB; bacteriocins; protective cultures

\section{Introduction}

Listeria monocytogenes is one of the most important pathogenic microorganisms and is responsible for causing listeriosis, an illness that affects mainly pregnant women, newborns, the elderly, and individuals with compromised immune systems [1]. Although it is a relatively rare illness, with a notification rate of 0.46 cases per 100,000 people in 2019 in the European Union (EU), most of the infections required hospitalisation (92.1\%) [2]. This microorganism is a serious concern in the ready-to-eat (RTE) meat and dairy products industries, including dry-cured fermented sausages or ripened cheeses [3-5], since it could colonize and grow in raw material and pre-processed products throughout the processing and/or storage of these products, posing a risk for the consumers and/or also provoking non-compliance of microbiological criteria for this pathogen bacterium. Although in most of these RTE ripened foods, the reduction of water activity $\left(\mathrm{a}_{\mathrm{w}}\right)$ and $\mathrm{pH}$ throughout the ripening are hurdles that aid to control L. monocytogenes, this pathogen has been involved in many outbreaks linked to the consumption of the above products [3,6-8].

The use of lactic acid bacteria (LAB) as protective cultures could be an additional tool to control L. monocytogenes in RTE meat and dairy-ripened products. LAB have been frequently used as starter or protective cultures due to their natural ability to dominate the microbial population of many foods where they naturally occur due to their ability to catabolize carbohydrates to lactic acid and produce other biologically active compounds, such as organic acids, diacetyl, hydrogen peroxide, and antibacterial peptides and flavour 
precursors [9]. In addition, screening natural LAB strains to find the ones able to produce antimicrobial molecules is a promising strategy. An important number of either bacteriostatic or bactericidal compounds produced by LAB has been described [10].

The LAB genera are Carnobacterium, Lactococcus, Leuconostoc, Oenococcus, Pediococcus, Streptococcus, and the former Lactobacillus genus, which has been recently reclassified into 25 new genera [11,12]. Most of them have the status Generally Recognised as Safe (GRAS) according to the U.S. Food and Drug Administration (FDA). In addition, many LAB species have the recognition of Qualified Presumption of Safety (QPS) from the European Food Safety Authority (EFSA) (Table 1); thus, they have this presumptive qualification of being safe to be used as protective cultures in foods.

Table 1. LAB included in the 2020 updated list of QPS status recommended biological agents for safety risk assessments carried out by EFSA Scientific Panels and Units [11].

\begin{tabular}{lll} 
Bifidobacterium adolescentis & Lactobacillus delbruechkii & Ligilactobacillus animalis \\
Bifidobacterium animalis & Lactobacillus gallinarum & Ligilactobacillus aviaries \\
Bifidobacterium bifidum & Lactobacillus gasseri & Ligilactobacillus salivarius \\
Bifidobacterium breve & Lactobacillus helveticus & Liminosilactobacillus fermentum \\
Bifidobacterium longum & Lactobacillus johnsonii & Liminosilactobacillus mucosae \\
Carnobacterium divergens & Lactobacillus kefiranofaciens & Liminosilactobacillus panis \\
Companilactobacillus alimentarius & Lactococcus lactis & Liminosilactobacillus pontis \\
Companilactobacillus farciminis & Lapidilactobacillus dextrinicus & Liminosilactobacillus reuteri \\
Corynebacterium ammoniagenes & Latilactobacillus curvatus & Loigolactobacillus coryniformis \\
Corynebacterium glutamicum & Latilactobacillu sakei & Microbacterium imperial \\
Fructilactobacillus sanfranciscensis & Lentilactobacillus buchneri & Oenococcus oeni \\
Lacticaseibacillus casei & Lentilactobacillus diolivorans & Pasteuria nishizawae \\
Lacticaseibacillus paracasei & Lentilactobacillus hilgardii & Pediococcus acidilactici \\
Lacticaseibacillus rhamnosus & Lentilactobacillus kefiri & Pediococcus parvulus \\
Lactiplantibacillus pentosus & Lentilactobacillus parafarraginis & Pediococcus pentosaceus \\
Lactiplantibacillus plantarum & Lentilactobacillus paraplantarum & Propionibacterium acidipropionici \\
Lactobacillus acidophilus & Leuconostoc citreum & Propionibacterium freudenreichii \\
Lactobacillus amylolyticus & Leuconostoc lactis & Secundilactobacillus collinoides \\
Lactobacillus amylovorus & Leuconostoc mesenteroides & Streptococcus thermophilus \\
Lactobacillus cellobiosus & Leuconostoc pseudomesenteroides & \\
Lactobacillus crispatus & Levilactobacillus brevis & \\
\hline & &
\end{tabular}

Although many LAB strains have been isolated and selected for their ability to in vitro inhibit L. monocytogenes, not all of them have been effectives in real RTE ripened food systems. In the present work, the strategies of selection of effective LAB species against $L$. monocytogenes to be used in RTE meat products and dairy-ripened products will be reviewed. In addition, we will also review the mechanism by which they inhibit $L$. monocytogenes as well as effective methods of LAB application and their metabolites in these kinds of products to control this pathogen throughout their processing and storage.

\section{Selection and Evaluation of LAB from RTE Meat and Dairy-Ripened Products with Anti-L. monocytogenes Activity}

Many traditional RTE fermented foods constitute rich ecological niches for screening LAB with anti-L. monocytogenes activity [13-15]. The selection of LAB with anti-L. monocytogenes activity from these products to be used as protective cultures should be performed from strains adapted to the ecological niche of these products since they must survive and are competitive in conditions of processing and/or storage. Thus, LAB strains should be isolated during ripening and/or storage conditions of meat and dairy-ripened products following different steps (Figure 1). First, LAB isolate should be obtained from meat and dairy-ripened products, testing different days of ripening (for example initial, half, and final time) or in different days of storage, with the purpose to obtain strains adapted to characteristics and processing conditions of the chosen foods. Then, isolated strains should be preliminary characterized by Gram staining, catalase reaction, shape by microscopic observation of overnight cultures, and biochemical features, as it has been reported in LAB strains isolation from soft cheese [16,17] or dry-cured fermented sausages [18]. After the first preliminary characterization, the isolates are screened for anti-L. monocytogenes in 
culture media usually by the agar spot-on-a-lawn method [14,19]. Thus, preliminary active isolates against L. monocytogenes are obtained, which are characterized by $16 \mathrm{~S}$ rRNA sequencing [17] and further evaluated by co-inoculation with L. monocytogenes for anti-listerial activity in food models simulating temperature, water activity, and $\mathrm{pH}$ conditions of RTE products, as it has been reported by Martín et al. (Unpublished data) in soft cheese model for the selection of active anti-listerial LAB strains (Figure 1). This step is of the utmost importance to discard LAB strains lacking activity or with low activity in the processing or storage conditions of RTE foods. Thus, active LAB strains against L. monocytogenes able to be finally evaluated in RTE products are selected. In parallel, the selected LAB strains should be finally characterized by some additional method to the 16 rRNA sequencing, which allow the differentiation at strain level. This should be of great value to evaluate implantation of selected strains in RTE foods in the next step. Pulsed-field gel electrophoresis analysis (PFGE) has been reported as an appropriate method for the differentiation of LAB strains [20]. In addition, the RFLP analysis of the tuf gene has also been described as a suitable tool for the differentiation of LAB strains [21].

Finally, it should be investigated the ability of the most effective LAB strains to control the growth of L. monocytogenes in the food product by the challenge test methodology (Figure 1), as it has been reported in dry-cured fermented sausages [22] and ripened cheeses [16]. These authors have found the ripening reduction of L. monocytogenes from 2 to $5 \log$ CFU/g because of the action of selected LAB strains. In addition, the assayed strains were successfully implanted in the food matrices.

Many studies have focused on the selection of LAB to reduce or eliminate L. monocytogenes in foods [23]. Campagnollo et al. [16] reported the isolation and characterization of LAB strains with anti-listerial activity and their effects on L. monocytogenes during refrigerated shelf-life of soft and ripening of semi-hard cheese. De Carvalho et al. [24] tested several LAB isolated from naturally fermented Italian salami for antagonistic activity against L. monocytogenes. Pedonese et al. [25] stated that Lactilactobacillus ( $L l)$ sakei is capable of suppressing the growth of pathogenic and spoilage microorganisms and improving the sensory quality of fresh meat preparations and products.

Most of the selected LAB strains with anti-L. monocytogenes activity have also been evaluated for possible modification of physicochemical $\left(\mathrm{pH}\right.$, humidity content, $\left.\mathrm{a}_{\mathrm{w}}\right)$, biochemical (proteolysis, lipolysis, volatile compounds generation), and sensorial parameters before being proposed as protective or starter cultures $[16,26]$. This evaluation allows to rule out some LAB strains that could negatively affect the physicochemical properties of RTE products and propose only those strains without effect or with positive repercussion on sensorial characteristic. All the former works have selected and characterized LAB strains that are available to be used as protective cultures in RTE meat and dairy-ripened products due to their effect against L. monocytogenes. 


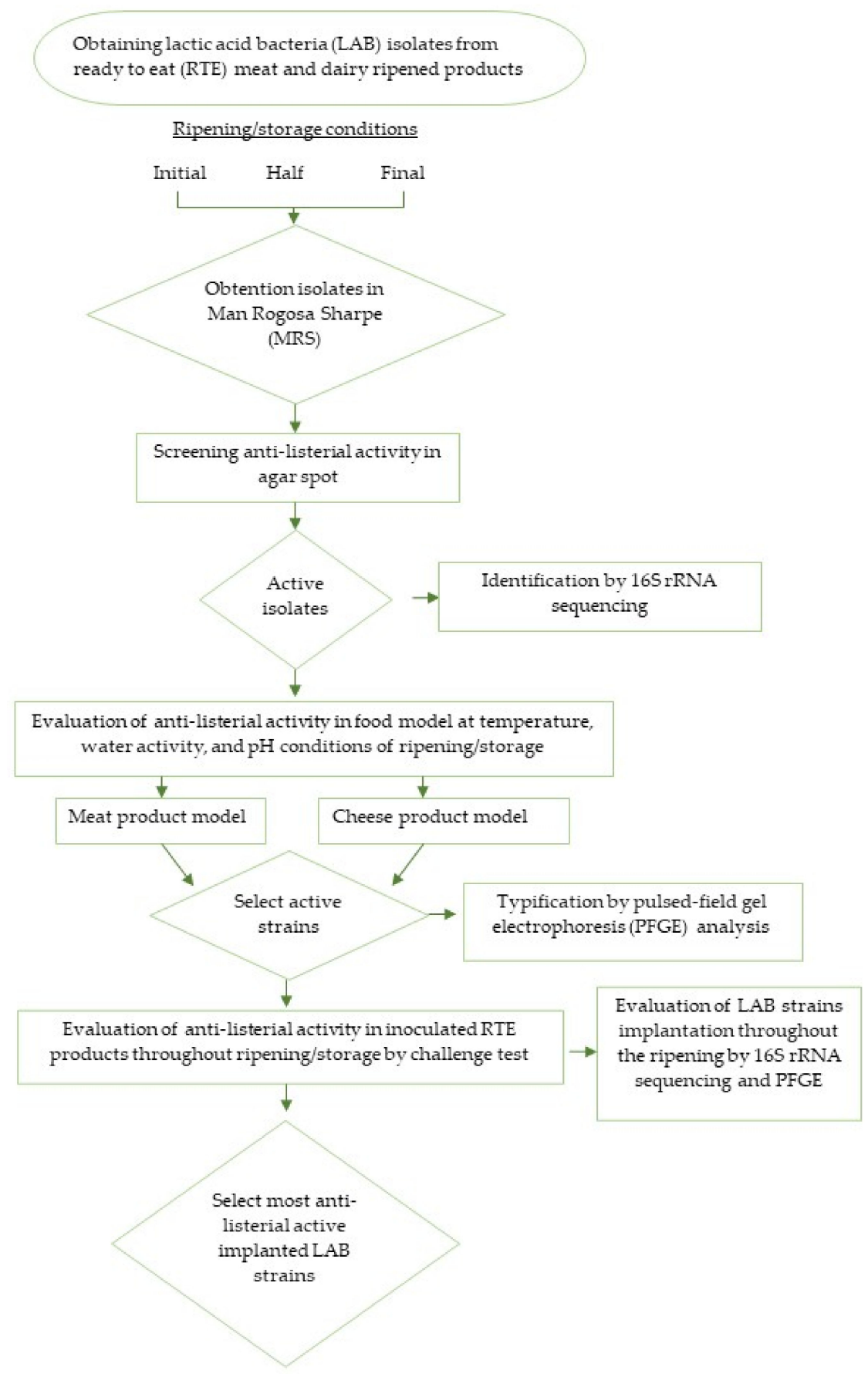

Figure 1. Diagrammatic flowchart for the isolation and selection of LAB strains with anti-listerial activity from RTE meat and dairy foods.

\section{Effect of Selected LAB Strains on L. monocytogenes Inhibition}

LAB mechanisms for L. monocytogenes inhibition in RTE foods include (a) production of inhibitory compounds, (b) competition for nutrients, (c) prevention of pathogen adhesion, and (d) competition for space or niche competition.

\subsection{Production of Inhibitory Compounds}

LAB have the ability to produce antimicrobial compounds, such as lactic acid and other organic acids, ethanol, diacetyl, carbon dioxide, hydrogen peroxide, bacteriocins, or bactericidal proteins [27]. Table 2 shows a summary of these compounds and their mechanisms of action. 
Table 2. Inhibitory compounds produced by selected LABs and their mechanisms of action against pathogens microorganisms, such as L. monocytogenes.

\begin{tabular}{ccc}
\hline Inhibitory Compound & Mechanism of Action & References \\
\hline Lactic acid and other volatile & Disruption of cellular metabolism & {$[27]$} \\
acids & Membrane fluidity and integrity & {$[28]$} \\
Ethanol & $\begin{array}{c}\text { Inactivation of essential biomolecules } \\
\text { by superoxide anion chain reaction }\end{array}$ & {$[29]$} \\
Hydrogen peroxide & Anaerobic environment and/or & \\
& inhibition of enzyme decarboxylation & {$[30]$} \\
Carbon dioxide & Inderference with arginine utilization & {$[29]$} \\
Diacetyl & Disruption of cytoplasmic membrane & {$[27,31]$} \\
\hline
\end{tabular}

Homofermentative LAB ferment carbohydrates to produce lactic acid as the major metabolic product, leading to $\mathrm{pH}$ reduction of food and also directly to growth inhibition of many microorganisms [32]. It has been described that the principal antimicrobial compound responsible for their activity against pathogens is synthesis of organic acids, mainly lactic and acetic acids $[28,33]$. Organic acids act by acidifying the intracellular $\mathrm{pH}$, generating an unfavourable local microenvironment for pathogenic bacteria [28,34]. They also act by inhibiting the active transport of excess internal protons that leads to the depletion of cellular energy [35]. The bacterial cell wall and the cytoplasmic membrane are the main targets of organic acids provoking alteration and death and metabolic functions of pathogenic microorganisms [36]. It has been proven that concentrations of $0.5 \%(v / v)$ of lactic acid could completely disrupt the growth of pathogenic microorganisms, such as Salmonella spp., Escherichia coli, or L. monocytogenes [37]. Wemmenhove et al. [38] tested the effect of lactic acid against L. monocytogenes in Gouda cheese. In addition, it has been studied that the short-chain fatty acids produced by LAB in food fermentation improve the integrity of the barrier and prevent the adhesion of pathogenic bacteria or indirectly inhibit the expression of the virulence genes at the transcriptional level of L. monocytogenes.

However, heterofermentative LAB produce lactic acid and additional compounds, such ethanol and carbon dioxide [39,40]. Ethanol produced by heterofermentative LAB affects membrane fluidity and integrity, leading to plasma membrane leakage and causing bacterial death [28]. Barker and Park [41] found that a 5\% ethanol concentration inhibited the replication of $L$. monocytogenes.

Some LAB strains produce hydrogen peroxide (Table 2) that provokes inactivation of essential biomolecules of the pathogens, such as L. monocytogenes, by superoxide anion chain reaction negatively affects its viability [29]. Thus, in vitro inhibition of L. monocytogenes mainly due to production of hydrogen peroxide was reported by Ghalfi et al. [42] with an Ll. curvatus selected strain from meat origin.

Heterofermentative LAB strains also produce carbon dioxide as a by-product of sugar fermentation that inhibits growth of L. monocytogenes [27,30].

Some LAB strains produce diacetyl, which interferes with arginine utilization of pathogen microorganisms, such as L. monocytogenes [29]. In fact, the combination of some bacteriocins, such as reuterin and diacetyl, have been reported to be anti-microbial additives with effects against L. monocytogenes [43].

Bacteriocins are produced by some LAB strains and contribute to the biological control of pathogenic and spoilage microorganisms. Bacteriocins and their effect against L. monocytogenes are detailed in the following section (Section 4).

\subsection{Competition for Nutrients}

One of the main mechanisms of action of non-pathogenic bacteria against pathogenic bacteria is competition for nutrients in a specific niche, leading to depletion [44]. The metabolic activity of L. monocytogenes may not be affected by antimicrobial compounds 
produced by LAB (bacteriocins, organic acids including lactic, and acetic acids) due to its acid tolerance and synthesis of proteolytic enzymes. Therefore, the growth rate of LAB is of great importance in their role in competing for nutrients with L. monocytogenes [45].

However, under stress conditions provoked by the lack of nutrients or acid stress caused by the organic acids synthesized by LAB, L. monocytogenes can express some of its virulence factors, such as InlA and InlB protein, to confront this stress [46]. In the same way, LAB may induce the synthesis of bacteriocins as a method to minimize the stress caused by insufficient nutrients [44].

\subsection{Competition for Space}

Another mechanism of action of LAB includes the competitive exclusion of pathogenic microorganisms from space [47]. Adhesion of L. monocytogenes on host cells is of great importance for their invasion and virulence [44,48]. LAB can prevent the binding of L. monocytogenes on host cells by colonizing the host cells and/or saturating the pathogen binding receptor [44]. Corr et al. [49] showed that pre-treatment of intestinal epithelial cells with LAB before infection with L. monocytogenes resulted in a significant decrease in its invasion (60-90\%). When there is a direct cell-to-cell competition between L. monocytogenes and $\mathrm{LAB}$ to the binding sites, $\mathrm{LAB}$ inhibit the attachment of the pathogen, being reduced by 4.38 and $3.22 \log$ CFU/g after $24 \mathrm{~h}$ and $72 \mathrm{~h}$, respectively [50]. According to Pilchová et al. [51], a significant inhibition of the adhesion, invasion, and transepithelial translocation of $L$. monocytogenes was obtained using Lacticaseibacillus $(L c)$ paracasei but only if this strain was recombined to obtain the expression of the adhesion protein of L. monocytogenes.

Competitive inhibition of selected LAB strains has been reported in biofilm formation of L. monocytogenes, which poses a risk factor in the food industry [52]. These authors found that selected Ll. curvatus, Lactococcus (La) lactis, Lactobacillus helveticus, and Weissella viridescens isolated from Brazilian's foods developed protective biofilms against L. monocytogenes hampering the biofilm formation by this pathogen, mostly due the exopolysaccharide production by these LAB strains. Thus, selected LAB strains could be promissory candidates for controlling the presence of L. monocytogenes biofilms in food-processing facilities [50].

\subsection{Reduction of L. monocytogenes Virulence by $L A B$}

Many authors have studied the use of LAB to reduce the expression of virulence of pathogens by modulating the expression of genes or proteins through bacterial signalling mechanisms. Thus, Dutra et al. [53] reported that Lc. casei and Lc. rhamnosus significantly reduced the binding (10-13\%) and invasion ( $40-50 \%$ ) of L. monocytogenes into cells, indicating that LAB are effective in reducing this pathogen colonization both when administered prophylactically and during infection. Another study by Upadhyay et al. [54] demonstrated that Liminosilactobacillus (Li) reuteri, Li. fermentum, Lactiplantibacillus (Lp) plantarum, and La. lactic reduced the adhesion and invasion of Caco-2 cell of L. monocytogenes, downregulating the expression of the majority of virulence genes of this pathogen $(p l c A, p l c B$, iap, $h l y$, inlA, inlB, act $A$, and $\operatorname{prf} A$ ).

A significant reduction in L. monocytogenes virulence on epithelial cells was observed when the cell monolayers were mixed with Carnobacterium divergens V41 cultures during $1 \mathrm{or} 4 \mathrm{~h}$. The ability to control foodborne pathogenic microorganism virulence has previously been evaluated for probiotic $\mathrm{LAB}$ and found to be strain specific. For example, Garriga et al. [55] reported a that bacteriocinogenic Ll. sakei strain significantly decreased the adhesion of L. monocytogenes.

Winkelströter and De Martinis [56] showed that the bacteriocins produced by Enterococcus (E) faecium, Leuconostoc (Le) mesenteroides, and Ll. sakei significantly decreased the expression of $i n l A$ gene from different $L$. monocytogenes strains.

\section{Bacteriocins with Activity against L. monocytogenes}

Antimicrobial peptides or proteins produced by LAB are small, ribosomally synthesized, and possess activity against closely related Gram-positive bacteria, whereas producer 
bacteria are immune to their own proteinaceous metabolites [57]. In general, bacteriocinproducing strains mostly belong to the formerly named Lactobacillus and Lactococcus genera and are well-proven to have Generally Recognised as Safe (GRAS) status [58].

The antibacterial spectrum of bacteriocins frequently includes spoilage microorganisms and foodborne pathogens, such as L. monocytogenes and Staphylococcus aureus. In addition to their antimicrobial action towards these unwanted species, bacteriocins are believed to contribute to increasing the competitiveness of the producer strain [59].

So far, bacteriocins have been classified into four general classes attending to their composition and structural properties. The first class, termed as lantibiotics, contains unusual amino acids (i.e., lanthionines and $\beta$-methyllanthionines). The production of this class of bacteriocins involves post-translational modifications, which are well described for nisin [60]. The second one is comprehended by bacteriocins that do not contain lanthionine residues, being characterised by heat stability and their site of action as the cell membrane. The third one is composed by the large and heat-sensitive bacteriocins, and finally, the fourth class is bacteriocins containing other chemical moieties (carbohydrates and lipids) [61]. Subsequent subclassifications into these groups has been performed, as shown in Table 3.

Table 3. Bacteriocins classification, main features, examples of different bacteriocins, and their producer microorganisms.

\begin{tabular}{|c|c|c|c|c|}
\hline Class & Characteristics & Example & Producer & Reference \\
\hline Ia & Lantibiotics (<5 KDa) & Nisin & Lactococcus lactis & [62] \\
\hline $\mathrm{Ib}$ & $\begin{array}{l}\text { Carbacyclic } \\
\text { lantibiotics }\end{array}$ & $\begin{array}{l}\text { Labyrinthopeptien } \\
\text { A1 }\end{array}$ & $\begin{array}{c}\text { Actinomadura } \\
\text { nambiensis }\end{array}$ & [63] \\
\hline Ic & Sactibiotics & Subtilosin A & Bacillus subtilis & [64] \\
\hline IIa & $\begin{array}{c}\text { Heat-stable peptides } \\
\text { with N terminal- } \\
\text { YGNGV }\end{array}$ & $\begin{array}{l}\text { Pediocin PA-1, } \\
\text { sakacins A and P, } \\
\text { leucocin A, } \\
\text { garviecin LG34 }\end{array}$ & $\begin{array}{l}\text { Pediococcus pentosaceus, } \\
\text { Pediococcus acidilactici, } \\
\text { Lactilactobacillus sakei, } \\
\text { Lactococcus garvieae }\end{array}$ & [65-69] \\
\hline $\mathrm{IIlb}$ & $\begin{array}{l}\text { Two-peptide } \\
\text { bacteriocins }\end{array}$ & $\begin{array}{l}\text { Lactococcin } \mathrm{G}, \\
\text { plantaricin } \mathrm{EF} \\
\text { and JK }\end{array}$ & $\begin{array}{l}\text { Lactiplantibacillus } \\
\text { plantarum, } \\
\text { Lactococcus spp. }\end{array}$ & [70-72] \\
\hline IIc & Circular bacteriocins & $\begin{array}{c}\text { Enterocin AS-48, } \\
\text { gassericin A }\end{array}$ & $\begin{array}{l}\text { Lactococcus gasseri, } \\
\text { Enterococcus faecalis }\end{array}$ & {$[73,74]$} \\
\hline IId & $\begin{array}{c}\text { Single, linear, } \\
\text { nonpediocin-like } \\
\text { bacteriocins }\end{array}$ & $\begin{array}{c}\text { Thuricin S, } \\
\text { bactofencin A }\end{array}$ & $\begin{array}{c}\text { Bacillus thuringensis, } \\
\text { Ligilactobacillus } \\
\text { salivarius }\end{array}$ & {$[75,76]$} \\
\hline IIIa & $\begin{array}{c}\text { Heat labile, }>30 \mathrm{KDa} \\
\text { with hydrolase } \\
\text { activity }\end{array}$ & Lysostaphin & $\begin{array}{l}\text { Staphylococcus. } \\
\text { simulans biovar } \\
\text { staphylolyticus }\end{array}$ & [77] \\
\hline $\mathrm{IIIlb}$ & $\begin{array}{c}\text { Heat labile, > } 30 \mathrm{KDa} \\
\text { without hydrolase } \\
\text { activity }\end{array}$ & Helveticin & Lactobacillus helveticus & [78] \\
\hline IV & $\begin{array}{l}\text { Large complexes with } \\
\text { carbohydrate or lipid } \\
\text { moieties }\end{array}$ & Enterocin F4-9 & Enterococcus faecalis & [79] \\
\hline
\end{tabular}

Among all bacteriocins, the post-translationally modified class Ia nisin is probably the best-known bacteriocin with listericidal effect. Nisin's mechanism of action involves membrane permeabilization through binding to lipid II, the phenyl chain-linked donor of the peptidoglycan building blocks [80]. This lipid II is believed crucial to peptidoglycan synthesis, and nisin is considerably more active towards peptidoglycan-rich, Gram-positive microorganisms than Gram-negative ones, the latter being only affected by nisin in conjunction with chemically induced damage of the outer membrane [81]. This bacteriocin is approved as a preservative by the European Commission, named as E 234, intended for use in various dairy products, among others [82]. 
Apart from the well-known nisin, the II class bacteriocins and most concretely IIa class are the most commonly active against L. monocytogenes. Some of these bacteriocins include garviecin LG34, bifidocin A, leucocin C-607, pediocin GS4, plantaricin LPL-1, or pediocin PA-1 or sakacins $[65,83-87]$. These pediocin-like class IIa bacteriocins deploy great bacterial inhibition at nanomolar concentrations in relation to the high affinity to specific receptors or docking molecules [83]. One of these target receptors is the called mannose-phosphotransferase system (man-PTS), which phosphorylates and transports carbohydrates and other related substances, and the membrane components, ManY/IIC and ManZ/IID, belonging to man-PTS, form a membrane-located complex [88-90]. Additionally, these class IIa bacteriocins act on the cytoplasmic membrane of Gram-positive microorganisms, dissipating the transmembrane electrical potential and resulting in intracellular ATP depletion. Furthermore, they induce the leak of ions, amino acids, proteins, and nucleic acids by forming hydrophilic pores in target membranes $[87,91]$.

Although the nature of these compounds is able to inhibit L. monocytogenes, several strains from this pathogen have been able to develop a certain degree of resistance against bacteriocins. The two strategies deployed by resistant bacteria to counteract the bacteriocins effect are membrane surface charge and membrane fluidity [92,93].

For class I bacteriocins, such as nisin, changes in membrane lipid composition are involved in L. monocytogenes resistance [94], as well as phospholipids charges in interactions between artificial membranes and nisin [95,96]. For class Ila bacteriocins, their target, the man-PTS receptor, plays a key role in the resistance against this type of bacteriocins [97]. On one hand, the low expression of genes related to this receptor is directly linked to IIa-class bacteriocin resistance [98]. On the other hand, as occurs for leucocin A, changes in membrane fatty acid composition, increase in D-alanine content of wall teichoic acid, and increase in L-lysine content of membrane phospholipids are other common strategies elicited by class-IIa resistant L. monocytogenes.

To overcome the limitation of bacteriocin resistance by L. monocytogenes and maximize its inhibitory activity, the use of different bacteriocins combined or even a given bacteriocin in combination with technological or chemical treatments could provide an alternate approach to tackle this problem [99], enhancing the antimicrobial effect as discussed in Section 6.

\section{Selection of Bacteriocin-Producing Lactic Acid Bacteria and Bacteriocin Characterization}

A common requirement for any protective culture is the safety of these organisms irrespectively of the production of antimicrobial metabolites. The ability to produce biogenic amines, such as 2-phenylethylamine, putrescine, cadaverine, agmatine, spermine, spermidine, histamine, and tyramine, should also be ruled out by gene analyses [100]. Additionally, other unwanted genes involved in virulence, such as asa1, agg, efa $A$, hyl, esp, $c y l L_{L}, c y l L_{S}$, ace, and gelE, should also be tested with the aim to ensure the lack of virulence in the selected strain [101]. Finally, the antibiotic resistance must be evaluated both for the possible involvement of some of these bacteria, mainly E. faecalis and E. faecium, in human infections [102] and the induction of potential antimicrobial resistance through horizontal gene transference [103].

Once the safety characterisation has been considered, the first step to evaluate the production of bacteriocins would entail a screening based on the assessment of the antimicrobial activity of the cell-free medium (CFM) in which the candidate LAB has been grown. The most recommended conditions to maximize the bacteriocin in vitro production for LAB are Man Rogosa Sharpe broth, $\mathrm{pH} 5.5-6.5$, at $30-37^{\circ} \mathrm{C}$ for $24-48$ h [104]. After obtaining the CFM, the in vitro antimicrobial activity against $L$. monocytogenes should be tested by co-culturing, in which CFM is simultaneously added with L. monocytogenes, or by delayed culturing, in which broth medium is inoculated with the pathogen and incubated, followed by CFM addition after $6 \mathrm{~h}$ of incubation [105].

A relatively quick and cheap technique for bacteriocin characterization for those CFM showing any degree of inhibition on L. monocytogenes is the tricine SDS-PAGE analysis [106] 
after protein precipitation with 40,60 , and $80 \%$ ammonium sulphate [107]. This tool is useful for a primary characterization given that it informs about the presence or absence of any proteinaceous compound as well as displays information about the potential bacteriocin molecular weight if any band is found. Thus, it serves to categorize the potential bacteriocin within some of the compatible classes attending to this feature. Although it could be thought that the main limitation of this technique is the degree of purity of the proteinaceous precipitation, since generally a complex of proteinaceous compounds is excreted to the CFM, a simple method based on the evaluation of the anti-listerial activity of every band from a given sample by setting the tricine-SDS-PAGE onto a solid medium inoculated with L. monocytogenes is commonly used [108].

Whether the tricine-SDS-PAGE reveals a single band linked to a sample with antilisterial activity, apart from the information about the molecular weight, this band could be excised, digested, and analysed by high-resolution mass spectrometry to identify its aminoacidic sequence and similarities with other previously published bacteriocins by means of software analyses such as MASCOT [109].

With the aim to genetically characterize the ability of bacteriocin production by LAB, the detection of genes that encode for these metabolites deserves to be exploited. There are numerous target genes to evaluate its presence in food products and even the bacteriocin production through transcriptional analysis. Some of these genes have been used for characterizing LAB ability to produce bacteriocins [110,111]. However, to completely characterize the ability of bacteriocin production, the most recommended approach consists of whole-genome sequencing to evaluate the presence of any reported bacteriocin [107]. This tool additionally offers the possibility of sweeping the currently sequenced genome in the future with the aim to detect genes encoding for ulteriorly discovered bacteriocins.

The bacteriocins as bioprotective tool against L. monocytogenes could be split into two different applications: (a) the addition of the purified bacteriocin to the food and (b) the inoculation of the bacteriocin-producing LAB in the food. The former has been assayed with the well-known nisin to successfully inhibit L. monocytogenes in milk although the antilisterial effect depends on its chemical composition and the technological process at which the food has undergone [112]. Additionally, intrinsic mechanisms from milk to inhibit pathogens, such as lactoperoxidase, seem to work synergistically with this bacteriocin, resulting in maximizing the anti-listerial effect [113].

\section{Application of Selected LAB or Bacteriocins in RTE Dry-Cured Meat Products}

The meat industry has carried out extraordinary research efforts to minimize the appearance of outbreaks caused by foodborne L. monocytogenes. The application of selected LAB and/or their purified antimicrobial metabolites for the biopreservation of RTE drycured meat products has been increasing in the last years with promising results. Selected LAB strains or their metabolites have been directly incorporated into the meat products throughout the processing to reduce the hazard posed by the presence and growth of L. monocytogenes in these products.

With this aim, Ll. sakei has been widely employed in several studies with different results. García-Diez and Patarata [114] concluded that the addition of Ll. sakei at a concentration of $6 \log$ CFU/g did not provoke significant reduction in L. monocytogenes counts in a Portuguese dry-fermented sausage. However, Ortiz et al. [115] showed that Ll. sakei, when added to meat batter in Iberian chorizo, showed an anti-listerial activity at either 7 or $20^{\circ} \mathrm{C}$, reducing by $2 \log _{10}$ units the pathogen counts. In addition, Vaz-Velho et al. [116] demonstrated that Ll. sakei was enough to minimise L. monocytogenes counts (up to $2 \log \mathrm{CFU} / \mathrm{g}$ ) in a Portuguese salami-like product, Alheira. Selected Lp. plantarum has also been used to inhibit and control L. monocytogenes in RTE meat products. Thus, Kamiloglu et al. [117] evaluated the effect of five $L p$. plantarum (initially inoculated at $7 \log$ CFU/g) against $L$. monocytogenes in sucuk, a traditional dry-fermented sausage from Turkey. They observed a decrease in L. monocytogenes counts from 1 to $2.7 \log$ CFU/g for the different Lp. plantarum strains tested during ripening. In such work, they determined that acidification and pro- 
duction of bacteriocins and/or bacteriocin like peptides were the cause for the control of this pathogenic microorganism. Zanette et al. [118] tested the anti-listerial activity of two Lp. plantarum strains (one bacteriocin-producing strain and one bacteriocin non-producing strain) and found they were equally effective to limit L. monocytogenes growth $(\approx 1.7 \log$ $\mathrm{CFU} / \mathrm{g}$ reduction) from the initial levels of the pathogen $(4 \log \mathrm{CFU} / \mathrm{g})$.

The combination of selected active LAB, such as Ll. sakei (CRL1862), with bacteriocin combination and $2.5 \%$ lactic acid and acetic acid diminished the L. monocytogenes counts at levels lower than $2 \log \mathrm{CFU} / \mathrm{g}$ (from initial counts at 3-4 log CFU/g) in frankfurters from day 6 to day 36 at $10{ }^{\circ} \mathrm{C}$ [119]. However, no significant additional reductions were observed when selected $\mathrm{Ll}$. sakei was evaluated in combination of packing under vacuum or modified atmosphere packaging. Nikodinoska et al. [120] tested the antagonistic activity of Lp. plantarum alone and combined with nitrite (at two concentrations) against the pathogenic bacterium in a chorizo sausage model. Counts of L. monocytogenes were reduced with the addition of the LAB strain (ranging from 2.6 to $3.8 \mathrm{log}$ CFU/g depending on the nitrite concentration used). In samples where nitrite was not added, Lp. plantarum reduced L. monocytogenes growth but not until the end of ripening. On the contrary, Macieira et al. [121], who used bacteriocinogenic Lp. plantarum cultures (at a concentration of $6 \log$ CFU /g) in a traditional Portuguese fermented dry-cured sausage, did not have any antagonistic activity against L. monocytogenes (initially inoculated at $5 \log \mathrm{CFU} / \mathrm{g}$ ).

In the study carried out by Sadaghiani et al. [122], they checked the effect of one strain of Lp. plantarum (initially inoculated at $7 \mathrm{log} C F U / g$ ) in ground raw beef alone and in combination with a garlic extract $(1 \%)$. The LAB strain alone decreased the counts of the pathogen at $0.7 \log \mathrm{CFU} / \mathrm{g}$, but when combined with the garlic extract, this reduction was $1.5 \log \mathrm{CFU} / \mathrm{g}$.

Pediococcus $(P)$ acidilactici has also been quite utilised as a biopreservative to control the development of L. monocytogenes in RTE meat products. Cosansu et al. [123] demonstrated that the bacteriocin-producing $P$. acidilactici possessed a significant anti-listerial activity on sucuk but not on sliced turkey bread. P. acidilactici produced a reduction of $3.3 \log \mathrm{CFU} / \mathrm{g}$ L. monocytogenes counts after 8 days of sucuk fermentation at mild temperatures $\left(22-24{ }^{\circ} \mathrm{C}\right)$. On the other hand, Ortiz et al. [115] showed that a starter culture containing P. acidilactici in Iberian chorizo provoked an anti-listerial effect at $7{ }^{\circ} \mathrm{C}$.

Other researchers have focused on looking for other LAB species as biopreservatives to counteract and minimize the growth of L. monocytogenes in RTE meat products. Regarding $P$. pentosaceus, it was added individually and in combination with $P$. acidilacti in sliced fresh beef samples [124]. This study concluded that the use of $P$. pentosaceus alone or combined with $P$. acidilacti is promising since they limited the L. monocytogenes counts $<2 \log C F U / g$ on day 2. Li. reuteri is another LAB species used as biopreservative in the meat industry. Sadaghiani et al. [122] checked the anti-L. monocytogenes activity of a Li. reuteri strain in conjunction with garlic extract $(1 \%)$ in beef, concluding that the combination of garlic extract with $L i$. reuteri caused a $1.4 \log$ count reduction, while Li. reuteri alone only provoked a $0.5 \mathrm{log}$ reduction. Orihuel et al. [125] reported that a bacteriocinogenic E. mundtii strain had limited anti-L. monocytogenes activity in beef sausage when applied alone, but in combination with curing additives, reductions of $2 \mathrm{log}$ CFU/g counts were achieved. Finally, Castellano et al. [119] showed that the bacteriocin synthesized by Ll. curvatus possessed some bacteriostatic effect in frankfurters but lower than that shown by the bacteriocin produced by $\mathrm{Ll}$. sakei.

Some metabolites synthesized by LAB have also been utilised as a biopreservative to control L. monocytogenes in RTE meat products. Trinetta et al. [126] studied the antagonistic effect of sakacin A, a bacteriocin produced by Aureobasidium pullulans, when it was directly added to RTE turkey breasts and when incorporated in a pullulan film to package this product. Results showed that sakacin A directly applied to turkey decreased the L. monocytogenes counts by more than $2 \log \mathrm{CFU} / \mathrm{g}$, while sakacin A-containing pullulan films diminished its counts $3 \log$ CFU/g. Another bacteriocin that displayed anti-L. monocytogenes activity was nisin when was added in RTE turkey ham [127]. This bacteriocin was 
used in different concentrations (from 0.2 to $0.5 \%$ ), and its antagonistic effect increased as the concentration did, keeping the L. monocytogenes counts lower than the control in all treatments. Leucocin A is another bacteriocin used for L. monocytogenes control purposes in RTE meat products. This bacteriocin produced by Le. gelidum has been employed in wieners (sausages) to counteract L. monocytogenes [128]. The antimicrobial activity of this bacteriocin was lower than the previous ones, obtaining only a reduction of $1 \log \mathrm{CFU} / \mathrm{g}$ after 16 days of incubation at refrigeration temperatures.

\section{Application of Selected LAB or Bacteriocins in RTE Dairy-Ripened Products}

Most of the application of LAB species in dairy-ripened products have been reported in cheese throughout the ripening or storage. Thus, selected strains of $\mathrm{Ll}$. sakei and Lp. plantarum used as protective cultures in soft cheese reduced the loads of L. monocytogenes from 0.5 to almost $1 \log \mathrm{CFU} / \mathrm{g}$ during $1375 \mathrm{~h}$ of storage at $15^{\circ} \mathrm{C}$ [17]. Higher reduction was found in semi-hard cheeses ripened with L. brevis, Lp. plantarum, and E. faecalis, where L. monocytogenes counts were reduced by $4 \log$ CFU/g after 15 days of ripening in cheeses made with raw milk and after 21 days in cheese made with pasteurized milk [16].

Selected Lactococcus spp. has been widely used as protective cultures in cheese. Thus, Kondrotiene et al. [129] found a significant reduction in L. monocytogenes counts when three nisin A-producing La. lactis strains were applied to fresh cheese. In addition, selected strains of La. lactis subsp. lactis and E. durans as individual or mixed cultures have also been reported to provoke a reduction of 2-3 log CFU/g of L. monocytogenes during 35 days of storage at $4{ }^{\circ} \mathrm{C}$ of ultrafiltered cheese [130]. These authors underlined the potential application of the above LAB strains in bio-control of this pathogen bacterium during storage of ultrafiltered cheese.

Ll. sakei, La. lactis, and Carnobacterium strains selected from Gorgonzola cheese have been reported to provoke a notable inhibition at low level of contamination of L. monocytogenes $(2 \log$ CFU/g) in this kind of cheese [10]. This inhibition was found during the first stage of ripening (6 days), and L. monocytogenes cells were maintained below the EC limit $(<2 \log \mathrm{CFU} / \mathrm{g}$ ) for 60 days. However, these authors reported that when L. monocytogenes was inoculated on the cheese surface at the end of ripening process (after 50 days; $\mathrm{pH}$ : 6.7), only one of the selected La. lactis strains exerted a significant inhibition on the growth of this pathogen if the cheese was strictly maintained at $4{ }^{\circ} \mathrm{C}$.

Morandi et al. [10] underlined that the susceptibility of L. monocytogenes biotypes to LAB antimicrobial activity is strain dependent. Thus, a blend of different LAB strains could represent a more effective tool to develop protective culture for ripened cheeses. In this sense, combinations of different LAB strains have been proposed to be used as protective cultures in cheese. The combination of Lp. plantarum strain (initially inoculated at $8 \log \mathrm{CFU} / \mathrm{mL}$ ) with a nisin producer reduced $L$. monocytogenes to undetectable levels in cheese by day 28 of ripening [131]. Furthermore, these authors found that Lp. plantarum was much more effective in inhibiting L. monocytogenes when the nisin producer was attached than when it was alone.

Some studies have reported the use of bacteriocin produced by LAB for biopreservation of cheeses [132,133]. Nisin is the most frequently used although it has been reported as efficient in control L. monocytogenes only in fresh cheese $[134,135]$. An increase in antiL. monocytogenes activity has been suggested when combining nisin with a second bacteriocin [134]. Therefore, the use of nisin in combination with the IIa class bovicin HC5 in fresh cheese against L. monocytogenes has been reported to provoke a 4 log reduction of this pathogen after 9 days at refrigeration storage [136]. In ripened cheese, it has been proposed as most effective to use nisin-producing strain of Lc. lactis subsp. lactis for the milk before cheese production, provoking an initial reduction higher than 2 log CFU/g [137] since the use of nisin could have the problem of the regrowth during ripening of the surviving L. monocytogenes [134]. Other bacteriocins, such as pediocins, enterocins, and lactacins, have also been used on the surface of cheese and mainly in fresh cheese [138-140], but their utility in ripened cheese is limited. Thus, although it has been highlighted that the 
utilization of bacteriocins could contribute to the creation of low-salt and healthier formulations of cheeses and to the optimization of processing conditions without compromising the microbiological safety of these RTE foods [141], the problem of the regrowth during ripening of surviving $L$. monocytogenes should be considered, which it makes more effective the use of selected LAB than the direct addition of bacteriocins.

Furthermore, combinations of different preservation methods may act synergistically or provide higher protection than a single method alone [142]. Thus, the combination of selected LAB with antimicrobial compounds has been proposed. In this sense, it has been proposed that selected $\mathrm{La}$. lactis be used in combination with acid/sodium lactate (LASL-L-lactic acid 61\% (w/w) and L-sodium lactate 21\% (w/w)) [143]. The former authors found a total inhibition of L. monocytogenes strains in the first 50 days of ripening of Gorgonzola cheese when this combination was used, while LASL with selected C. divergens was more effective in the second part of ripening when the $\mathrm{pH}$ was raised. These authors encouraged the use of LASL along with antimicrobial LAB rotation schemes during cheese ripening for the prevention and/or control of the L. monocytogenes on the cheese surface of Gorgonzola cheese.

Finally, the use of active packaging with bacteriocins produced by selected LAB species is a promising strategy to control L. monocytogenes in packaged cheeses. In fact, Contessa et al. [144] described a film based on agar-agar incorporated with bacteriocin produced by a selected Lc. casei to be used as active packaging in curd cheese. This active packaging provokes a reduction of $3 \log _{10}$ units of pathogen bacteria, such as L. monocytogenes.

\section{Conclusions and Future Remarks}

L. monocytogenes is a serious concern in the RTE meat and dairy-ripened products industries. The use of LAB as protective cultures and/or their metabolites could be a promising tool to control L. monocytogenes in these kinds of products. Although LAB strains are present in most of the ripened foods as the natural microbial population, to find strains with anti-L. monocytogenes activity able to survive in conditions of ripened products, an appropriated selection methodology is necessary. This includes recovery of $\mathrm{LAB}$ isolates from different ripening/storage conditions and evaluation of the anti-listerial activity in food models simulating temperature, $\mathrm{a}_{\mathrm{w}}$, and $\mathrm{pH}$ conditions of the processing. Then, final selection should be performed after evaluation of the most active strains in food matrices, following the challenge test methodology. As a result of the proposed isolation and selection methods for LAB strains with the ability to produce antimicrobial compounds, such as lactic acid and other organic acids, ethanol, diacetyl, carbon dioxide, hydrogen peroxide, bacteriocins, are available. In addition, the selected LAB strains can compete for nutrients and space with L. monocytogenes and some of them are able to eliminate this pathogen bacterium from biofilm and reduce its virulence and the ability of L. monocytogenes to survive. These strains have showed effectivity in meat and dairyripened products, achieving reductions form $2-5 \log _{10}$ units of L. monocytogenes throughout the ripening process. This could be sufficient to guarantee the elimination of this pathogenic bacterium throughout the ripening/storage of RTE meat and dairy-ripened products when this pathogen contaminates these products at the usual levels (below $2 \log$ CFU/g). This is of utmost importance since minimizing the risk of listeriosis caused by the consumption of these products improves food safety and meets the microbiological criteria of RTE foods throughout their shelf life. Bacteriocins could be also used to control L. monocytogenes, but their activity in these products could be limited by the regrowth during ripening or storage of the surviving strains of this pathogen. Thus, the combination of different active LAB strains and those bacteriocigenic ones could be the most appropriate strategies to control L. monocytogenes in ripened foods. Furthermore, the combination of selected LAB strains with antimicrobial compounds, such as acid/sodium lactate, and other strategies for active packaging could be the next step to eliminate the risk posed by L. monocytogenes in meat and dairy-ripened products. 


\begin{abstract}
Author Contributions: Conceptualization, J.J.C. and A.R.; methodology, I.M.; writing —original draft preparation, I.M., J.D., A.R. and J.J.C.; writing-review and editing, I.M., J.D., A.R. and J.J.C.; funding acquisition, J.J.C.; supervision, J.J.C. and A.R.; project administration, J.J.C. All authors have read and agreed to the published version of the manuscript.
\end{abstract}

Funding: This work has been funded by the INIA throughout the project RTA-2017-00027-C03-03 (Spanish Ministry of Economy, Industry, and Competitiveness) and the Junta de Extremadura and FEDER by IB16149, GR15108, and GR18056.

Institutional Review Board Statement: Not applicable.

Informed Consent Statement: Not applicable.

Data Availability Statement: Not applicable.

Acknowledgments: I. Martín thanks the Spanish Ministry of Education, Culture and Sports because of her pre-doctoral fellowship (FPU 16/05303).

Conflicts of Interest: The authors declare no conflict of interest.

\title{
References
}

1. Baka, M.; Noriega, E.; Mertens, L.; Van Derlinden, E.; Van Impe, J.F.M. Protective role of indigenous Leuconostoc carnosum against Listeria monocytogenes on vacuum packed Frankfurter sausages at suboptimal temperatures. Food Res. Int. 2014, 66, 197-206. [CrossRef]

2. EFSA; ECDC. The European Union One Health 2019 Zoonoses Report. EFSA J. 2021, 19, 6406. [CrossRef]

3. EFSA; ECDC. Scientific opinion on the Listeria monocytogenes contamination of ready-to-eat foods and the risk for human health in the EU. EFSA J. 2018, 16, 1-173. [CrossRef]

4. Kurpas, M.; Wieczorek, K.; Osek, J. Ready-to-eat meat products as a source of Listeria monocytogenes. J. Vet. Res. 2018, 62, 49-55. [CrossRef]

5. Martinez-Rios, V.; Dalgaard, P. Prevalence of Listeria monocytogenes in European cheeses: A systematic review and meta-analysis. Food Control 2018, 84, 205-214. [CrossRef]

6. Fretz, R.; Sagel, U.; Ruppitsch, W.; Pietzka, A.T.; Stöger, A.; Huhulescu, S.; Heuberger, S.; Pichler, J.; Much, P.; Pfaff, G.; et al. Listeriosis outbreak caused by acid curd cheese "Quargel", Austria and Germany 2009. Eurosurveillance 2010, 15, 1-2. [CrossRef]

7. Cartwright, E.J.; Jackson, K.A.; Johnson, S.D.; Graves, L.M.; Silk, B.J.; Mahon, B.E. Listeriosis outbreaks and associated food vehicles, United States, 1998-2008. Emerg. Infect. Dis. 2013, 19, 1-9. [CrossRef]

8. Magalhães, R.; Almeida, G.; Ferreira, V.; Santos, I.; Silva, J.; Mendes, M.M.; Pita, J.; Mariano, G.; Mâncio, I.; Sousa, M.M. Cheese-related listeriosis outbreak, Portugal, march 2009 to february 2012. Eurosurveillance 2015, 20, 21104. [CrossRef]

9. Egan, K.; Field, D.; Rea, M.C.; Ross, R.P.; Hill, C.; Cotter, P.D. Bacteriocins: Novel solutions to age old spore-related problems? Front. Microbiol. 2016, 7, 461. [CrossRef]

10. Morandi, S.; Silvetti, T.; Battelli, G.; Brasca, M. Can lactic acid bacteria be an efficient tool for controlling Listeria monocytogenes contamination on cheese surface? The case of Gorgonzola cheese. Food Control 2019, 96, 499-507. [CrossRef]

11. EFSA BIOHAZ Panel. Updated list of QPS status recommended biological agents in support of EFSA risk assessments. EFSA J. 2021, 19, 1-5.

12. Zheng, J.; Wittouck, S.; Salvetti, E.; Franz, C.M.A.P.; Harris, H.M.B.; Mattarelli, P.; O'toole, P.W.; Pot, B.; Vandamme, P.; Walter, J.; et al. A taxonomic note on the genus Lactobacillus: Description of 23 novel genera, emended description of the genus Lactobacillus beijerinck 1901, and union of Lactobacillaceae and Leuconostocaceae. Int. J. Syst. Evol. Microbiol. 2020, 70, 2782-2858. [CrossRef]

13. Cocolin, L.; Foschino, R.; Comi, G.; Grazia Fortina, M. Description of the bacteriocins produced by two strains of Enterococcus faecium isolated from Italian goat milk. Food Microbiol. 2007, 24, 752-758. [CrossRef]

14. Sip, A.; Wieckowicz, M.; Olejnik-Schmidt, A.; Grajek, W. Anti-Listeria activity of lactic acid bacteria isolated from golka, a regional cheese produced in Poland. Food Control 2012, 26, 117-124. [CrossRef]

15. Xiraphi, N.; Georgalaki, M.; Rantsiou, K.; Cocolin, L.; Tsakalidou, E.; Drosinos, E.H. Purification and characterization of a bacteriocin produced by Leuconostoc mesenteroides E131. Meat Sci. 2008, 80, 194-203. [CrossRef]

16. Campagnollo, F.B.; Margalho, L.P.; Kamimura, B.A.; Feliciano, M.D.; Freire, L.; Lopes, L.S.; Alvarenga, V.O.; Cadavez, V.A.P.; Gonzales-Barron, U.; Schaffner, D.W.; et al. Selection of indigenous lactic acid bacteria presenting anti-listerial activity, and their role in reducing the maturation period and assuring the safety of traditional Brazilian cheeses. Food Microbiol. 2018, 73, 288-297. [CrossRef]

17. Panebianco, F.; Giarratana, F.; Caridi, A.; Sidari, R.; De Bruno, A.; Giuffrida, A. Lactic acid bacteria isolated from traditional Italian dairy products: Activity against Listeria monocytogenes and modelling of microbial competition in soft cheese. LWT 2021, 137, 110446. [CrossRef]

18. Papamanoli, E.; Tzanetakis, N.; Litopoulou-Tzanetaki, E.; Kotzekidou, P. Characterization of lactic acid bacteria isolated from a Greek dry-fermented sausage in respect of their technological and probiotic properties. Meat Sci. 2003, 65, 859-867. [CrossRef] 
19. Todorov, S.D.; Dicks, L.M.T. Characterization of bacteriocins produced by lactic acid bacteria isolated from spoiled black olives. J. Basic Microbiol. 2005, 45, 312-322. [CrossRef]

20. Picozzi, C.; Bonacina, G.; Vigentini, I.; Foschino, R. Genetic diversity in Italian Lactobacillus sanfranciscensis strains assessed by multilocus sequence typing and pulsed-field gel electrophoresis analyses. Microbiology 2010, 156, 2035-2045. [CrossRef]

21. Park, S.H.; Jung, J.H.; Seo, D.H.; Lee, H.L.; Kim, G.W.; Park, S.Y.; Shin, W.C.; Hong, S.; Park, C.S. Differentiation of lactic acid bacteria based on RFLP analysis of the tuf gene. Food Sci. Biotechnol. 2012, 21, 911-915. [CrossRef]

22. Martín, I.; Rodríguez, A.; Sánchez-Montero, L.; Padilla, P.; Córdoba, J.J. Effect of the dry-cured fermented sausage "salchichón" processing with a selected Lactobacillus sakei in Listeria monocytogenes and microbial population. Foods 2021, 10, 856. [CrossRef]

23. Bungenstock, L.; Abdulmawjood, A.; Reich, F. Evaluation of antibacterial properties of lactic acid bacteria from traditionally and industrially produced fermented sausages from Germany. PLoS ONE 2020, 15, e0230345. [CrossRef]

24. De Carvalho, A.A.T.; De Paula, R.A.; Mantovani, H.C.; De Moraes, C.A. Inhibition of Listeria monocytogenes by a lactic acid bacterium isolated from Italian salami. Food Microbiol. 2006, 23, 213-219. [CrossRef]

25. Pedonese, F.; Torracca, B.; Mancini, S.; Pisano, S.; Turchi, B.; Cerri, D.; Nuvoloni, R. Effect of a Lactobacillus sakei and Staphylococcus xylosus protective culture on Listeria monocytogenes growth and quality traits of Italian fresh sausage (salsiccia) stored at abusive temperature. Ital. J. Anim. Sci. 2020, 19, 1363-1374. [CrossRef]

26. dos Cruxen, C.E.S.; Funck, G.D.; Haubert, L.; da Dannenberg, G.S.; de Marques, J.L.; Chaves, F.C.; da Silva, W.P.; Fiorentini, Â.M. Selection of native bacterial starter culture in the production of fermented meat sausages: Application potential, safety aspects, and emerging technologies. Food Res. Int. 2019, 122, 371-382. [CrossRef] [PubMed]

27. Kasra-Kermanshahi, R.; Mobarak-Qamsari, E. Inhibition effect of lactic acid bacteria against food born pathogen, Listeria monocytogenes. Appl. Food Biotechnol. 2015, 2, 11-19. [CrossRef]

28. Vieco-Saiz, N.; Belguesmia, Y.; Raspoet, R.; Auclair, E.; Gancel, F.; Kempf, I.; Drider, D. Benefits and inputs from lactic acid bacteria and their bacteriocins as alternatives to antibiotic growth promoters during food-animal production. Front. Microbiol. 2019, 10, 57. [CrossRef]

29. Leroy, F.; De Vuyst, L. Lactic acid bacteria as functional starter cultures for the food fermentation industry. Trends Food Sci. Technol. 2004, 15, 67-78. [CrossRef]

30. Singh, V.P. Recent approaches in food bio-preservation-A review. Open Vet. J. 2018, 8, 104-111. [CrossRef]

31. Simons, A.; Alhanout, K.; Duval, R.E. Bacteriocins, antimicrobial peptides from bacterial origin: Overview of their biology and their impact against multidrug-resistant bacteria. Microorganisms 2020, 8, 639. [CrossRef] [PubMed]

32. Mokoena, M.P.; Omatola, C.A.; Olaniran, A.O. Applications of lactic acid bacteria and their bacteriocins against food spoilage microorganisms and foodborne pathogens. Molecules 2021, 26, 7055. [CrossRef] [PubMed]

33. Russo, P.; Arena, M.P.; Fiocco, D.; Capozzi, V.; Drider, D.; Spano, G. Lactobacillus plantarum with broad antifungal activity: A promising approach to increase safety and shelf-life of cereal-based products. Int. J. Food Microbiol. 2017, 247, 48-54. [CrossRef] [PubMed]

34. Dittoe, D.K.; Ricke, S.C.; Kiess, A.S. Organic acids and potential for modifying the avian gastrointestinal tract and reducing pathogens and disease. Front. Vet. Sci. 2018, 5, 1-12. [CrossRef]

35. Ricke, S.C. Perspectives on the use of organic acids and short chain fatty acids as antimicrobials. Poult. Sci. 2003, 82, 632-639. [CrossRef]

36. Nair, S.M.; Amalaradjou, M.A.; Venkitanarayanan, K. Antivirulence properties of probiotics in combating microbial pathogenesis. Adv. Appl. Microbiol. 2017, 98, 1-29. [CrossRef]

37. Wang, C.; Chang, T.; Yang, H.; Cui, M. Antibacterial mechanism of lactic acid on physiological and morphological properties of Salmonella Enteritidis, Escherichia coli and Listeria monocytogenes. Food Control 2015, 47, 231-236. [CrossRef]

38. Wemmenhove, E.; van Valenberg, H.J.F.; van Hooijdonk, A.C.M.; Wells-Bennik, M.H.J.; Zwietering, M.H. Factors that inhibit growth of Listeria monocytogenes in nature-ripened Gouda cheese: A major role for undissociated lactic acid. Food Control 2018, 84, 413-418. [CrossRef]

39. Mokoena, M.P.; Mutanda, T.; Olaniran, O. Perspectives on the probiotic potential of lactic acid bacteria from African traditional fermented foods and beverages Mduduzi. Food Nutr. Res. 2016, 60, 29630. [CrossRef]

40. Zúñiga, M.; Pardo, I.; Ferrer, S. An improved medium for distinguishing between homofermentative and heterofermentative lactic acid bacteria. Int. J. Food Microbiol. 1993, 18, 37-42. [CrossRef]

41. Barker, C.; Park, S.F. Sensitization of Listeria monocytogenes to low pH, organic acids, and osmotic stress by ethanol. Appl. Environ. Microbiol. 2001, 67, 1594-1600. [CrossRef]

42. Ghalfi, H.; Thonart, P.; Benkerroum, N. Inhibitory activity of Lactobacillus curvatus CWBI-B28 against Listeria monocytogenes and ST2-verotoxin producing Escherichia coli O157. Afr. J. Biotechnol. 2006, 5, 2303-2306. [CrossRef]

43. Langa, S.; Martín-Cabrejas, I.; Montiel, R.; Landete, J.M.; Medina, M.; Arqués, J.L. Short communication: Combined antimicrobial activity of reuterin and diacetyl against foodborne pathogens. J. Dairy Sci. 2014, 97, 6116-6121. [CrossRef]

44. Yap, P.-C.; MatRahim, N.-A.; AbuBakar, S.; Lee, H.Y. Antilisterial potential of lactic acid bacteria in eliminating Listeria monocytogenes in host and ready-to-eat food application. Microbiol. Res. 2021, 12, 234-257. [CrossRef]

45. Saraoui, T.; Fall, P.A.; Leroi, F.; Antignac, J.P.; Chéreau, S.; Pilet, M.F. Inhibition mechanism of Listeria monocytogenes by a bioprotective bacteria Lactococcus piscium CNCM I-4031. Food Microbiol. 2016, 53, 70-78. [CrossRef] 
46. Zilelidou, E.; Rychli, K.; Manthou, E.; Ciolacu, L.; Wagner, M.; Skandamis, P.N. Highly invasive Listeria monocytogenes strains have growth and invasion advantages in strain competition. PLoS ONE 2015, 10, e0141617. [CrossRef]

47. Bermudez-Brito, M.; Plaza-Díaz, J.; Muñoz-Quezada, S.; Gómez-Llorente, C.; Gil, A. Probiotic mechanisms of action. Ann. Nutr. Metab. 2012, 61, 160-174. [CrossRef]

48. Herich, R.; Levkut, M. Lactic acid bacteria, probiotics and immune system. Vet. Med. 2002, 47, 169-180. [CrossRef]

49. Corr, S.C.; Gahan, C.G.M.; Hill, C. Impact of selected Lactobacillus and Bifidobacterium species on Listeria monocytogenes infection and the mucosal immune response. FEMS Immunol. Med. Microbiol. 2007, 50, 380-388. [CrossRef]

50. Ndahetuye, J.B.; Koo, O.K.; O’Bryan, C.A.; Ricke, S.C.; Crandall, P.G. Role of lactic acid bacteria as a biosanitizer to prevent attachment of Listeria monocytogenes F6900 on deli slicer contact surfaces. J. Food Prot. 2012, 75, 1429-1436. [CrossRef]

51. Pilchová, T.; Pilet, M.F.; Cappelier, J.M.; Pazlarová, J.; Tresse, O. Protective effect of Carnobacterium spp. against Listeria monocytogenes during host cell invasion using in vitro HT29 model. Front. Cell. Infect. Microbiol. 2016, 6, 88. [CrossRef] [PubMed]

52. Gómez, N.C.; Ramiro, J.M.P.; Quecan, B.X.V.; de Melo Franco, B.D.G. Use of potential probiotic lactic acid bacteria (LAB) biofilms for the control of Listeria monocytogenes, Salmonella Typhimurium, and Escherichia coli O157: H7 biofilms formation. Front. Microbiol. 2016, 7, 1-15. [CrossRef] [PubMed]

53. Dutra, V.; Silva, A.C.; Cabrita, P.; Peres, C.; Malcata, X.; Brito, L. Lactobacillus plantarum LB95 impairs the virulence potential of Gram-positive and Gram-negative food-borne pathogens in HT-29 and vero cell cultures. J. Med. Microbiol. 2016, 65, 28-35. [CrossRef] [PubMed]

54. Upadhyay, A.; Upadhyaya, I.; Mooyottu, S.; Venkitanarayanan, K. Eugenol in combination with lactic acid bacteria attenuates Listeria monocytogenes virulence in vitro and in invertebrate model Galleria mellonella. J. Med. Microbiol. 2016, 65, 443-455. [CrossRef] [PubMed]

55. Garriga, M.; Rubio, R.; Aymerich, T.; Ruas-Madiedo, P. Potentially probiotic and bioprotective lactic acid bacteria starter cultures antagonise the Listeria monocytogenes adhesion to HT29 colonocyte-like cells. Benef. Microbes 2015, 6, 337-343. [CrossRef]

56. Winkelströter, L.K.; De Martinis, E.C.P. Effect of bacteriocins and conditions that mimic food and digestive tract on biofilm formation, in vitro invasion of eukaryotic cells and Internalin gene expression by Listeria monocytogenes. Probiotics Antimicrob. Proteins 2013, 5, 153-164. [CrossRef]

57. De Vuyst, L.; Leroy, F. Bacteriocins from lactic acid bacteria: Production, purification, and food applications. J. Mol. Microbiol. Biotechnol. 2007, 13, 194-199. [CrossRef]

58. Pessione, E. Lactic acid bacteria contribution to gut microbiota complexity: Lights and shadows. Front. Cell. Infect. Microbiol. 2012, 2, 86. [CrossRef]

59. Vogel, R.F.; Pohle, B.S.; Tichaczek, P.S.; Hammes, W.P. The competitive advantage of Lactobacillus curvatus LTH 1174 in sausage fermentations is caused by formation of curvacin A. Syst. Appl. Microbiol. 1993, 16, 457-462. [CrossRef]

60. Cheigh, C.I.; Pyun, Y.R. Nisin biosynthesis and its properties. Biotechnol. Lett. 2005, 27, 1641-1648. [CrossRef]

61. Klaenhammer, T.R. Genetics of bacteriocins produced by lactic acid bacteria. FEMS Microbiol. Rev. 1993, 12, 39-85. [CrossRef]

62. Deegan, L.H.; Cotter, P.D.; Hill, C.; Ross, P. Bacteriocins: Biological tools for bio-preservation and shelf-life extension. Int. Dairy J. 2006, 16, 1058-1071. [CrossRef]

63. Férir, G.; Petrova, M.I.; Andrei, G.; Huskens, D.; Hoorelbeke, B.; Snoeck, R.; Vanderleyden, J.; Balzarini, J.; Bartoschek, S.; Brönstrup, M.; et al. The lantibiotic peptide labyrinthopeptin A1 demonstrates broad anti-HIV and anti-HSV activity with potential for microbicidal applications. PLoS ONE 2013, 8, e64010. [CrossRef]

64. Kawulka, K.E.; Sprules, T.; Diaper, C.M.; Whittal, R.M.; McKay, R.T.; Mercier, P.; Zuber, P.; Vederas, J.C. Structure of subtilosin A, a cyclic antimicrobial peptide from Bacillus subtilis with unusual sulfur to $\alpha$-carbon cross-links: Formation and reduction of $\alpha$-Thio- $\alpha$-Amino acid derivatives. Biochemistry 2004, 43, 3385-3395. [CrossRef]

65. Gao, Y.; Li, D.; Liu, S.; Zhang, L. Garviecin LG34, a novel bacteriocin produced by Lactococcus garvieae isolated from traditional Chinese fermented cucumber. Food Control 2015, 50, 896-900. [CrossRef]

66. Fimland, G.; Jack, R.; Jung, G.; Nes, I.F.; Nissen-Meyer, J. The bactericidal activity of pediocin PA-1 is specifically inhibited by a 15-mer fragment that spans the bacteriocin from the Center toward the C terminus. Appl. Environ. Microbiol. 1998, 64, 5057-5060. [CrossRef]

67. Chen, H.; Tian, F.; Li, S.; Xie, Y.; Zhang, H.; Chen, W. Cloning and heterologous expression of a bacteriocin sakacin P from Lactobacillus sakei in Escherichia coli. Appl. Microbiol. Biotechnol. 2012, 94, 1061-1068. [CrossRef]

68. Trinetta, V.; Morleo, A.; Sessa, F.; Iametti, S.; Bonomi, F.; Ferranti, P. Purified sakacin A shows a dual mechanism of action against Listeria spp: Proton motive force dissipation and cell wall breakdown. FEMS Microbiol. Lett. 2012, 334, 143-149. [CrossRef]

69. Ceuppens, S.; De Coninck, D.; Bottledoorn, N.; Van Nieuwerburgh, F.; Uyttendaele, M. Microbial community profiling of fresh basil and pitfalls in taxonomic assignment of enterobacterial pathogenic species based upon 16S rRNA amplicon sequencing. Int. J. Food Microbiol. 2017, 257, 148-156. [CrossRef]

70. Ekblad, B.; Nissen-Meyer, J.; Kristensen, T. Whole-genome sequencing of mutants with increased resistance against the twopeptide bacteriocin plantaricin JK reveals a putative receptor and potential docking site. PLoS ONE 2017, 12, e0185279. [CrossRef]

71. Ekblad, B.; Kyriakou, P.K.; Oppegård, C.; Nissen-Meyer, J.; Kaznessis, Y.N.; Kristiansen, P.E. Structure-function analysis of the two-peptide bacteriocin plantaricin EF. Biochemistry 2016, 55, 5106-5116. [CrossRef] [PubMed]

72. Oppegård, C.; Rogne, P.; Kristiansen, P.E.; Nissen-Meyer, J. Structure analysis of the two-peptide bacteriocin lactococcin G by introducing D-amino acid residues. Microbiology 2010, 156, 1883-1889. [CrossRef] [PubMed] 
73. Gálvez, A.; Maqueda, M.; Martínez-Bueno, M.; Valdivia, E. Bactericidal and bacteriolytic action of peptide antibiotic AS-48 against gram-positive and gram-negative bacteria and other organisms. Res. Microbiol. 1989, 140, 57-68. [CrossRef]

74. Pandey, N.; Malik, R.K.; Kaushik, J.K.; Singroha, G. Gassericin A: A circular bacteriocin produced by Lactic acid bacteria Lactobacillus gasseri. World J. Microbiol. Biotechnol. 2013, 29, 1977-1987. [CrossRef]

75. Chehimi, S.; Pons, A.M.; Sablé, S.; Hajlaoui, M.R.; Limam, F. Mode of action of thuricin S, a new class IId bacteriocin from Bacillus thuringiensis. Can. J. Microbiol. 2010, 56, 162-167. [CrossRef]

76. O'Shea, E.F.; O'Connor, P.M.; O'Sullivan, O.; Cotter, P.D.; Ross, R.P.; Hill, C. Bactofencin A, a new type of cationic bacteriocin with Unusual Immunity. mBio 2013, 4, e00498-13. [CrossRef]

77. Schindler, C.A.; Schuhardt, V.T. Lysostaphin; a new bacteriolytic agent for the Staphylococcus. Proc. Natl. Acad. Sci. USA 1964, 51, 414-421. [CrossRef]

78. Vaughan, E.E.; Daly, C.; Fitzgerald, G.F. Identification and characterization of helveticin V-1829, a bacteriocin produced by Lactobacillus helveticus 1829. J. Appl. Bacteriol. 1992, 73, 299-308. [CrossRef]

79. Maky, M.A.; Ishibashi, N.; Zendo, T.; Perez, R.H.; Doud, J.R.; Karmi, M.; Sonomoto, K. Enterocin F4-9, a novel O-linked glycosylated bacteriocin. Appl. Environ. Microbiol. 2015, 81, 4819-4826. [CrossRef]

80. Breukink, E.; Van Heusden, H.E.; Vollmerhaus, P.J.; Swiezewska, E.; Brunner, L.; Walker, S.; Heck, A.J.R.; De Kruijff, B. Lipid II is an intrinsic component of the pore induced by nisin in bacterial membranes. J. Biol. Chem. 2003, 278, 19898-19903. [CrossRef]

81. Breukink, E.; De Kruijff, B. The lantibiotic nisin, a special case or not? Biochim. Biophys. Acta-Biomembr. 1999, 1462, $223-234$. [CrossRef]

82. European Commission. Commission Regulation (EU) No 1129/2011 of 11 November 2011 amending Annex II to Regulation (EC) No 1333/2008 of the European Parliament and of the Council by establishing a Union list of food additives. Off. J. Eur. Union 2011, L295, 1-177. [CrossRef]

83. Zhu, L.; Zeng, J.; Wang, C.; Wang, J. Structural basis of pore formation in the mannose phosphotransferase system (man-PTS) by pediocin PA-1. Appl. Environ. Microbiol. 2021, 88, e0199221. [CrossRef]

84. Schillinger, U.; Kaya, M.; Lücke, F.-K. Behaviour of Listeria monocytogenes in meat and its control by a bacteriocin-producing strain of Lactobacillus sake. J. Appl. Bacteriol. 1991, 70, 473-478. [CrossRef]

85. Chen, Y.; Wu, H.; Kuo, C.; Chen, Y.; Ho, S.; Yanagida, F. Leucocin C-607, a Novel Bacteriocin from the multiple-bacteriocinproducing Leuconostoc pseudomesenteroides 607 isolated from persimmon. Probiotics Antimicrob. Proteins 2018, 10, 148-156. [CrossRef]

86. Liu, G.; Ren, L.; Song, Z.; Wang, C.; Sun, B. Purification and characteristics of bifidocin A, a novel bacteriocin produced by Bifidobacterium animals BB04 from centenarians' intestine. Food Control 2015, 50, 889-895. [CrossRef]

87. Wang, Y.; Qin, Y.; Zhang, Y.; Wu, R.; Li, P. Antibacterial mechanism of plantaricin LPL-1, a novel class IIa bacteriocin against Listeria monocytogenes. Food Control 2019, 97, 87-93. [CrossRef]

88. Diep, D.B.; Skaugen, M.; Salehian, Z.; Holo, H.; Nes, I.F. Common mechanisms of target cell recognition and immunity for class II bacteriocins. Proc. Natl. Acad. Sci. USA 2007, 104, 2384-2389. [CrossRef]

89. Jeckelmann, J.M.; Erni, B. The mannose phosphotransferase system (Man-PTS)—Mannose transporter and receptor for bacteriocins and bacteriophages. Biochim. Biophys. Acta-Biomembr. 2020, 1862, 183412. [CrossRef]

90. Liu, X.; Zeng, J.; Huang, K.; Wang, J. Structure of the mannose transporter of the bacterial phosphotransferase system. Cell Res. 2019, 29, 680-682. [CrossRef]

91. Chikindas, M.L.; Garcia-Garcera, M.J.; Driessen, A.J.M.; Ledeboer, A.M.; Nissen-Meyer, J.; Nes, I.F.; Abee, T.; Konings, W.N.; Venema, G. Pediocin PA-1, a bacteriocin from Pediococcus acidilactici PAC1.0, forms hydrophilic pores in the cytoplasmic membrane of target cells. Appl. Environ. Microbiol. 1993, 59, 3577-3584. [CrossRef]

92. Moll, G.N.; Konings, W.N.; Driessen, A.J.M. Bacteriocins: Mechanism of membrane insertion and pore formation. Antonie Van Leeuwenhoek Int. J. Gen. Mol. Microbiol. 1999, 76, 185-198. [CrossRef]

93. Rashid, R.; Veleba, M.; Kline, K.A. Focal targeting of the bacterial envelope by antimicrobial peptides. Front. Cell Dev. Biol. 2016, 4 , 1-13. [CrossRef]

94. Mazzotta, A.S.; Montville, T.J. Nisin induces changes in membrane fatty acid composition of Listeria monocytogenes nisin-resistant strains at $10^{\circ} \mathrm{C}$ and $30^{\circ} \mathrm{C}$. J. Appl. Microbiol. 1997, 82, 32-38. [CrossRef]

95. Demel, R.A.; Peelen, T.; Siezen, R.J.; De Kruijff, B.; Kuipers, O.P. Nisin Z, mutant nisin Z and lacticin 481 interactions with anionic lipids correlate with antimicrobial activity: A monolayer study. Eur. J. Biochem. 1996, 235, 267-274. [CrossRef]

96. Van Kraaij, C.; Breukink, E.; Noordermeer, M.A.; Demel, R.A.; Siezen, R.J.; Kuipers, O.P.; De Kruijff, B. Pore formation by nisin involves translocation of its C-terminal part across the membrane. Biochemistry 1998, 37, 16033-16040. [CrossRef]

97. Gravesen, A.; Ramnath, M.; Rechinger, K.B.; Andersen, N.; Jänsch, L.; Héchard, Y.; Hastings, J.W.; Knøchel, S. High-level resistance to class IIa bacteriocins is associated with one general mechanism in Listeria monocytogenes. Microbiology 2002, 148, 2361-2369. [CrossRef]

98. Opsata, M.; Nes, I.F.; Holo, H. Class IIa bacteriocin resistance in Enterococcus faecalis V583: The mannose PTS operon mediates global transcriptional responses. BMC Microbiol. 2010, 10, 224. [CrossRef]

99. Kumariya, R.; Garsa, A.K.; Rajput, Y.S.; Sood, S.K.; Akhtar, N.; Patel, S. Bacteriocins: Classification, synthesis, mechanism of action and resistance development in food spoilage causing bacteria. Microb. Pathog. 2019, 128, 171-177. [CrossRef] 
100. Barbieri, F.; Montanari, C.; Gardini, F.; Tabanelli, G. Biogenic amine production by lactic acid bacteria: A review. Foods $2019,8,17$. [CrossRef]

101. Biscola, V.; Choiset, Y.; Rabesona, H.; Chobert, J.M.; Haertlé, T.; Franco, B.D.G.M. Brazilian artisanal ripened cheeses as sources of proteolytic lactic acid bacteria capable of reducing cow milk allergy. J. Appl. Microbiol. 2018, 125, 564-574. [CrossRef] [PubMed]

102. Bintsis, T. Lactic acid bacteria as starter cultures: An update in their metabolism and genetics. AIMS Microbiol. 2018, 4, 665-684. [CrossRef] [PubMed]

103. Marshall, B.M.; Levy, S.B. Food animals and antimicrobials: Impacts on human health. Clin. Microbiol. Rev. 2011, $24,718-733$. [CrossRef] [PubMed]

104. Oliveira, M.; Barbosa, J.; Albano, H.; Teixeira, P. Bacteriocinogenic activity of Leuconostoc lactis RK18 isolates from fermented food. In Fermented Foods; Oliver, K., Ed.; Nova Science Publishers, Inc.: New York, NY, USA, 2020; Chapter 3; p. 159.

105. Mariam, S.H.; Zegeye, N.; Tariku, T.; Andargie, E.; Endalafer, N.; Aseffa, A. Potential of cell-free supernatants from cultures of selected lactic acid bacteria and yeast obtained from local fermented foods as inhibitors of Listeria monocytogenes, Salmonella spp. and Staphylococcus aureus. BMC Res. Notes 2014, 7, 606. [CrossRef]

106. Schägger, H.; von Jagow, G. Tricine-sodium dodecyl sulfate-polyacrylamide gel electrophoresis for the separation of proteins in the range from 1 to $100 \mathrm{kDa}$. Anal. Biochem. 1987, 166, 368-379. [CrossRef]

107. Barbosa, J.; Albano, H.; Silva, B.; Almeida, M.H.; Nogueira, T.; Teixeira, P. Characterization of a Lactiplantibacillus plantarum r23 isolated from arugula by whole-genome sequencing and its bacteriocin production ability. Int. J. Environ. Res. Public Health 2021, 18, 5515. [CrossRef]

108. Abrams, D.; Barbosa, J.; Albano, H.; Silva, J.; Gibbs, P.A.; Teixeira, P. Characterization of bacPPK34 a bacteriocin produced by Pediococcus pentosaceus strain K34 isolated from "Alheira". Food Control 2011, 22, 940-946. [CrossRef]

109. Nebbia, S.; Lamberti, C.; Lo Bianco, G.; Cirrincione, S.; Laroute, V.; Cocaign-Bousquet, M.; Cavallarin, L.; Giuffrida, M.G.; Pessione, E. Antimicrobial potential of food lactic acid bacteria: Bioactive peptide decrypting from caseins and bacteriocin production. Microorganisms 2021, 9, 65. [CrossRef]

110. Azizi, F.; Habibi Najafi, M.B.; Dovom, M.R.E. The biodiversity of Lactobacillus spp. from Iranian raw milk Motal cheese and antibacterial evaluation based on bacteriocin-encoding genes. AMB Express 2017, 7, 1-10. [CrossRef]

111. Ho, V.T.T.; Lo, R.; Bansal, N.; Turner, M.S. Characterisation of Lactococcus lactis isolates from herbs, fruits and vegetables for use as biopreservatives against Listeria monocytogenes in cheese. Food Control 2018, 85, 472-483. [CrossRef]

112. Bhatti, M.; Veeramachaneni, A.; Shelef, L.A. Factors affecting the antilisterial effects of nisin in milk. Int. J. Food Microbiol. 2004, 97, 215-219. [CrossRef]

113. Zapico, P.; Medina, M.; Gaya, P.; Nuñez, M. Synergistic effect of nisin and the lactoperoxidase system on Listeria monocytogenes in skim milk. Int. J. Food Microbiol. 1998, 40, 35-42. [CrossRef]

114. García-Díez, J.; Patarata, L. Influence of salt level, starter culture, fermentable carbohydrates, and temperature on the behaviour of L. monocytogenes in sliced chouriço during storage. Acta Aliment. 2017, 46, 206-213. [CrossRef]

115. Ortiz, S.; López, V.; Garriga, M.; Martínez-Suárez, J.V. Antilisterial effect of two bioprotective cultures in a model system of Iberian chorizo fermentation. Int. J. Food Sci. Technol. 2014, 49, 753-758. [CrossRef]

116. Vaz-Velho, M.; Jácome, S.; Noronha, L.; Todorov, S.; Fonseca, S.; Pinheiro, R.; Morais, A.; Silva, J.; Teixeira, P. Comparison of antilisterial effects of two strains of lactic acid bacteria during processing and storage of a portuguese salami-like product alheira. Chem. Eng. Trans. 2013, 32, 1807-1812. [CrossRef]

117. Kamiloglu, A.; Kaban, G.; Kaya, M. Effects of autochthonous Lactobacillus plantarum strains on Listeria monocytogenes in sucuk during ripening. J. Food Saf. 2019, 39, 1-8. [CrossRef]

118. Zanette, C.M.; Dalla Santa, O.R.; Bersot, L.S. Effect of Lactobacillus plantarum starter cultures on the behavior of Listeria monocytogenes during sausage maturation. Int. Food Res. J. 2015, 22, 844-848.

119. Castellano, P.; Peña, N.; Ibarreche, M.P.; Carduza, F.; Soteras, T.; Vignolo, G. Antilisterial efficacy of Lactobacillus bacteriocins and organic acids on frankfurters. Impact on sensory characteristics. J. Food Sci. Technol. 2018, 55, 689-697. [CrossRef]

120. Nikodinoska, I.; Baffoni, L.; Di Gioia, D.; Manso, B.; García-Sánchez, L.; Melero, B.; Rovira, J. Protective cultures against foodborne pathogens in a nitrite reduced fermented meat product. LWT 2019, 101, 293-299. [CrossRef]

121. Macieira, A.; Barros, D.; Vaz-Velho, M.; Pinheiro, R.; Fonseca, S.; Albano, H.; Teixeira, P. Effects of Lactobacillus plantarum bacteriocinogenic culture on physicochemical, microbiological, and sensorial characteristics of "Chouriço Vinha d'Alhos", A traditional Portuguese Sausage. J. Food Qual. Hazards Control 2018, 5, 118-127. [CrossRef]

122. Khalili Sadaghiani, S.; Aliakbarlu, J.; Tajik, H.; Mahmoudian, A. Anti-Listeria activity and shelf life extension effects of Lactobacillus along with garlic extract in ground beef. J. Food Saf. 2019, 39, 1-8. [CrossRef]

123. Cosansu, S.; Geornaras, I.; Ayhan, K.; Sofos, J.N. Control of Listeria monocytogenes by bacteriocin-producing Pediococcus acidilactici 13 and its antimicrobial substance in a dry fermented sausage sucuk and in turkey breast. J. Food Nutr. Res. 2010, 49, $206-214$.

124. Olaoye, O.A.; Onilude, A.A. Investigation on the potential application of biological agents in the extension of shelf life of fresh beef in Nigeria. World J. Microbiol. Biotechnol. 2010, 26, 1445-1454. [CrossRef]

125. Orihuel, A.; Bonacina, J.; Vildoza, M.J.; Bru, E.; Vignolo, G.; Saavedra, L.; Fadda, S. Biocontrol of Listeria monocytogenes in a meat model using a combination of a bacteriocinogenic strain with curing additives. Food Res. Int. 2018, 107, 289-296. [CrossRef]

126. Trinetta, V.; Floros, J.D.; Cutter, C.N. Sakacin a-containing pullulan film: An active packaging system to control epidemic clones of Listeria monocytogenes in ready-to-eat foods. J. Food Saf. 2010, 30, 366-381. [CrossRef] 
127. Ruiz, A.; Williams, S.K.; Djeri, N.; Hinton, A.; Rodrick, G.E. Nisin affects the growth of Listeria monocytogenes on ready-to-eat turkey ham stored at four degrees Celsius for sixty-three days. Poult. Sci. 2010, 89, 353-358. [CrossRef]

128. Balay, D.R.; Dangeti, R.V.; Kaur, K.; McMullen, L.M. Purification of leucocin A for use on wieners to inhibit Listeria monocytogenes in the presence of spoilage organisms. Int. J. Food Microbiol. 2017, 255, 25-31. [CrossRef]

129. Kondrotiene, K.; Kasnauskyte, N.; Serniene, L.; Gölz, G.; Alter, T.; Kaskoniene, V.; Maruska, A.S.; Malakauskas, M. Characterization and application of newly isolated nisin producing Lactococcus lactis strains for control of Listeria monocytogenes growth in fresh cheese. LWT-Food Sci. Technol. 2018, 87, 507-514. [CrossRef]

130. Ivanovic, M.; Mirkovic, N.; Mirkovic, M.; Miocinovic, J.; Radulovic, A.; Knudsen, T.S.; Radulovic, Z. Autochthonous Enterococcus durans PFMI565 and Lactococcus lactis subsp. lactis BGBU1-4 in bio-control of Listeria monocytogenes in ultrafiltered cheese. Foods 2021, 10, 1448. [CrossRef]

131. Mills, S.; Serrano, L.M.; Griffin, C.; O'Connor, P.M.; Schaad, G.; Bruining, C.; Hill, C.; Ross, R.P.; Meijer, W.C. Inhibitory activity of Lactobacillus plantarum LMG P-26358 against Listeria innocua when used as an adjunct starter in the manufacture of cheese. Microb. Cell Fact. 2011, 10, 1-11. [CrossRef]

132. Hernández, D.; Cardell, E.; Zárate, V. Antimicrobial activity of lactic acid bacteria isolated from Tenerife cheese: Initial characterization of plantaricin TF711, a bacteriocin like substance produced by Lactobacillus plantarum TF711. J. Appl. Microbiol. 2005, 99, 77-84. [CrossRef] [PubMed]

133. O'Sullivan, L.; O'Connor, E.; Ross, R.; Hill, C. Evaluation of live-culture producing lacticin 3147 as a treatment for the control of Listeria monocytogenes on the surface of smear-ripened cheese. J. Appl. Microbiol. 2006, 100, 135-143. [CrossRef] [PubMed]

134. Falardeau, J.; Trmčić, A.; Wang, S. The occurrence, growth, and biocontrol of Listeria monocytogenes in fresh and surface-ripened soft and semisoft cheeses. Compr. Rev. Food Sci. Food Saf. 2021, 20, 4019-4048. [CrossRef] [PubMed]

135. Lourenço, A.; Kamnetz, M.B.; Gadotti, C.; Diez-Gonzalez, F. Antimicrobial treatments to control Listeria monocytogenes in queso fresco. Food Microbiol. 2017, 64, 47-55. [CrossRef]

136. de Pimentel-Filho, N.J.; Mantovani, H.C.; de Carvalho, A.F.; Dias, R.S.; Vanetti, M.C.D. Efficacy of bovicin HC5 and nisin combination against Listeria monocytogenes and Staphylococcus aureus in fresh cheese. Int. J. Food Sci. Technol. 2014, 49, 416-422 [CrossRef]

137. Dal Bello, B.; Cocolin, L.; Zeppa, G.; Field, D.; Cotter, P.D.; Hill, C. Technological characterization of bacteriocin producing Lactococcus lactis strains employed to control Listeria monocytogenes in Cottage cheese. Int. J. Food Microbiol. 2012, 153, 58-65. [CrossRef]

138. Loessner, M.; Guenther, S.; Steffan, S.; Scherer, S. A pediocin-producing Lactobacillus plantarum strain inhibits Listeria monocytogenes in a multispecies cheese surface microbial ripening consortium. Appl. Environ. Microbiol. 2003, 69, 1854-1857. [CrossRef]

139. Ribeiro, S.C.; O'Connor, P.M.; Ross, R.P.; Stanton, C.; Silva, C.C.G. An anti-listerial Lactococcus lactis strain isolated from Azorean Pico cheese produces lacticin 481. Int. Dairy J. 2016, 63, 18-28. [CrossRef]

140. Ribeiro, S.C.; Ross, R.P.; Stanton, C.; Silva, C.C.G. Characterization and application of antilisterial enterocins on model fresh cheese. J. Food Prot. 2017, 80, 1303-1316. [CrossRef]

141. Possas, A.; Bonilla-Luque, O.M.; Valero, A. From cheese-making to consumption: Exploring the microbial safety of cheeses through predictive microbiology models. Foods 2021, 10, 335. [CrossRef]

142. Arqués, J.L.; Rodríguez, E.; Langa, S.; Landete, J.M.; Medina, M. Antimicrobial activity of lactic acid bacteria in dairy products and gut: Effect on pathogens. Biomed Res. Int. 2015, 2015, 584183. [CrossRef]

143. Morandi, S.; Silvetti, T.; Vezzini, V.; Morozzo, E.; Brasca, M. How we can improve the antimicrobial performances of lactic acid bacteria? A new strategy to control Listeria monocytogenes in Gorgonzola cheese. Food Microbiol. 2020, 90, 103488. [CrossRef]

144. Contessa, C.R.; De Souza, N.B.; Batt, G.; De Moura, C.M.; Silveira, G.; Moraes, C.C. Development of active packaging based on agar-agar incorporated with bacteriocin of Lactobacillus sakei. Biomolecules 2021, 11, 1869. [CrossRef] 